\title{
Distribution of serovariants of group B streptococci in isolates from England and Norway
}

\author{
A. I. KVAM, A. EFSTRATIOU*, L. BEVANGER, B. D. COOKSON†, I. F. MARTICORENA*, \\ R. C. GEORGE* and J. A. MAELAND
}

Department of Microbiology, Faculty of Medicine, University of Trondheim, N-7006 Trondheim, Norway, ${ }^{*}$ Respiratory and Systemic Infection Laboratory and $\uparrow$ Laboratory of Hospital Infection, Central Public Health Laboratory, London NW9 5HT, UK

\begin{abstract}
Summary. The distribution of capsular polysaccharide antigen (CHO) types, surface-exposed c proteins $\alpha\left(c^{\alpha}\right)$ and $\beta\left(c^{\beta}\right)$ and an R-protein antigen was examined in 334 group B streptococci (GBS) isolates from three groups of patients hospitalised in England and Wales or Norway. The isolates were from 108 carriers, 67 cases of neonatal infection and 154 cases of adult infection. Each group contained all CHO types (Ia, Ib, II, III, IV, V and NT); type III strains predominated except in the adult infected group. Strains within each $\mathrm{CHO}$ type could be further subdivided by the protein markers into five subtypes by a combined typing system. The proportion of type Ib and type III strains in the neonatal infection cases and of type $\mathrm{Ib}$ strains in the adult infection cases significantly outnumbered isolates of these serotypes among the carrier strains. Twenty-nine different serovariants were identified; 24,13 and 23 serovariants among the carrier, neonatal infection and adult infection isolates, respectively. Certain CHO antigen-protein associations were identified, notably those between Ia/ $\mathrm{c}^{\alpha}$, $\mathrm{Ib} / \mathrm{c}^{\alpha \beta}$ and III/R. The proportion of invasive isolates that expressed protein was not higher than in the carrier isolates. All CHO-type Ib isolates contained a c protein, but $7 \%$ of the $\mathrm{Ib}$ isolates did not contain any of these proteins. These findings indicate that this combined typing approach may be useful in examining epidemiological problems associated with GBS.
\end{abstract}

\section{Introduction}

Group B streptococci (GBS) are major causes of neonatal sepsis and meningitis and are also recognised as occasional pathogens in adults. ${ }^{1}$ Traditionally, GBS have been classified or typed serologically on the basis of the capsular polysaccharide ( $\mathrm{CHO}$ ) antigens designated Ia, Ib, II and III. Typability and discrimination in the CHO typing system are poor and, therefore, alternative methods of typing GBS isolates have been explored, e.g., bacteriophage typing, ${ }^{2}$ multilocus enzyme electrophoresis ${ }^{3}$ and restriction endonuclease analysis. ${ }^{4,5}$

More recently it has been realised that, in addition to the CHO antigens, GBS may produce surfacelocalised $c$ and $R$ protein antigens. ${ }^{6,7}$ The $c$ protein was called Ibc protein ${ }^{8}$ and comprises two proteins, the $\alpha$ and $\beta$ antigens. ${ }^{9}$ Both proteins have been characterised extensively. ${ }^{10-12}$ It has been shown that GBS isolates vary in the expression of both $\alpha$ and $\beta$ protein $^{13}$ and others have shown a similar picture for the strepto-

Received 20 Sept. 1994; accepted 5 Oct. 1994. coccal $\mathrm{R}$ protein antigens, of which the $\mathrm{R} 4$ protein is particularly prevalent in GBS. ${ }^{14}$ To date however, there has been no systematic assessment of the typing potential of a system that combines these different serological approaches.

The present study was designed to explore whether the combined use of $\mathrm{CHO}$ and protein antigens in a GBS typing system could increase discrimination and typability. A total of 334 GBS strains collected in hospitals in England and Wales and Norway during 1990-1993 was tested and data on serovariant distribution amongst carriers and cases of infection were assessed.

\section{Materials and methods}

\section{Isolates examined}

Of a total of 334 GBS examined, 233 isolates came from England and Wales and 101 from Norway. The strains were from infected patients or carriers and were referred from different hospitals throughout the two countries, from 1990 to 1993. All patient isolates were from sporadic cases and duplicate outbreak isolates 
were not included. No GBS epidemic was recorded in either country during the period of collection. GBS from carriers $(n=108)$ were skin isolates from neonates (35) or vaginal isolates (73) from adults. Of the 226 isolates from invasive GBS infection, 68 were from neonates, 45 from blood cultures and 23 from cerebrospinal fluid or pus; of the 158 isolates from adults, 101 were from blood cultures and 57 from pleural effusions or pus.

\section{Preservation and culture}

The isolates were preserved in Greaves's medium at $-80^{\circ} \mathrm{C}$. Preparations of GBS for testing were made from bacteria cultured on blood agar at $37^{\circ} \mathrm{C}$ for $18 \mathrm{~h}$.

\section{Testing of antigenic markers}

The bacteria were identified by the Streptex kit (Murex) as recommended by the manufacturer. For isolates from England and Wales, CHO type was determined by immunodiffusion in agar gel with $\mathrm{HCl}$ extracts and rabbit antisera. ${ }^{15}$ Isolates from Norway were tested for $\mathrm{CHO}$ antigen by a direct immunofluorescent assay with fluorescein isothiocyanateconjugated IgG from rabbit antisera. ${ }^{16}$ Surface-exposed protein markers of GBS, the $\mathrm{c}$ proteins $\alpha\left(\mathrm{c}^{\alpha}\right)$ and $\beta\left(\mathrm{c}^{\beta}\right)$, were tested by an indirect immunofluorescent assay with monoclonal antibodies (MAbs) ; ${ }^{17,18}$ a presumed $R$ protein was examined by a MAb produced recently. ${ }^{19}$ Slides with GBS were prepared and the tests were performed and interpreted as described previously. ${ }^{16}$

\section{Results}

\section{Test performance}

Only 25 isolates produced equivocal results when tested for the $\mathrm{CHO}$ or protein markers and these were re-examined. Isolates from England and Wales were serotyped by immunodiffusion in agar gel and those from Norway by an immunofluorescent assay; 15 isolates were tested by both methods with similar results. Isolates for $\mathrm{CHO}$ and protein markers were subcultured and tested repeatedly for up to 15 years and no reduction in antibody activity has been noted.

\section{Overall serotype and subtype distribution}

The CHO type and subtype distribution among GBS from England and Wales and Norway were similar. Of the 334 GBS isolates examined, 303 (91\%) belonged to one of the CHO types Ia, Ib, II, III, IV or $\mathrm{V}$ (table I). The remaining $31(9 \%)$ isolates were nontypable and have been considered as a separate serotype (type NT). Type III occurred most frequently, followed by type Ib, Ia and type II.

One or two of the protein antigen markers were expressed by $279(84 \%)$ of the isolates $-\mathrm{c}$ protein by $171(51 \%)$ and $\mathrm{R}$ protein by $108(32 \%)$. Of the $\mathrm{c}$ proteins $\mathrm{c}^{\alpha}$ alone occurred with the highest frequency, followed by the $\mathrm{c}^{\alpha \beta}$ combination and $\mathrm{c}^{\beta}$ alone. No isolate expressed both $\mathrm{c}$ and $\mathrm{R}$ proteins.

Strains of all seven CHO types expressed protein, but some of the $\mathrm{CHO}$ antigens were more likely to be associated with one or two particular proteins than with other proteins. This association is shown in fig. 1. The Ia subtype $\mathrm{Ia} / \mathrm{c}^{\alpha}$ ( $74 \%$ of Ia isolates) greatly outnumbered other Ia subtypes $(\mathrm{p}<0.001)$ and the $\mathrm{Ib}$ subtype $\mathrm{Ib} / \mathrm{c}^{\alpha \beta}(42 \%)$ and the type III subtype III/R $(75 \%)$ outnumbered other type Ib and type III subtypes $(p<0.001)$. None of the 71 type Ib strains expressed the R antigen and five (7\%) of the Ib strains also failed to express $\mathrm{c}$ protein. No particular subtype predominated in type II strains. Of the protein antigen markers, $\mathrm{c}^{\alpha}$ was most widely distributed among isolates of different CHO types; 29 serovariants were found among the 334 isolates (table I).

\section{Distribution of $C H O$ and protein markers in GBS of different clinical origins}

Tables II and III show the distribution of the markers in carrier and invasive isolates and fig. 2 illustrates the predominant subtypes within the most

Table 1. Distribution of capsular antigen (CHO) types and protein markers among 334 GBS isolates from England and Wales and Norway

\begin{tabular}{|c|c|c|c|c|c|c|}
\hline \multirow{2}{*}{$\begin{array}{l}\text { CHO } \\
\text { serotype }\end{array}$} & \multicolumn{5}{|c|}{ Protein antigen marker* } & \multirow{2}{*}{$\begin{array}{c}\text { Total } \\
\text { number }\end{array}$} \\
\hline & $c^{\alpha}$ & $\mathrm{c}^{\alpha \beta}$ & $\mathrm{c}^{\beta}$ & $\mathbf{R}$ & None & \\
\hline Ia & 43 & 8 & & 1 & 6 & $58(17 \cdot 4)$ \\
\hline $\mathrm{Ib}$ & 15 & 37 & 14 & & 5 & $71(21 \cdot 3)$ \\
\hline II & 11 & 11 & 3 & 7 & 3 & $35(10 \cdot 5)$ \\
\hline III & 2 & 1 & & 85 & 25 & $113(33.8)$ \\
\hline IV & 9 & & 1 & & 1 & $11(3 \cdot 3)$ \\
\hline V & 2 & 1 & 1 & 7 & 7 & $18(5.4)$ \\
\hline NT & 8 & 4 & & 8 & 8 & $28(8 \cdot 1)$ \\
\hline $\begin{array}{l}\text { Total number } \\
(\%)\end{array}$ & $\begin{array}{l}90 \\
(26.9)\end{array}$ & $\begin{array}{c}62 \\
(18 \cdot 6)\end{array}$ & $\begin{array}{l}19 \\
(5 \cdot 7)\end{array}$ & $\begin{array}{l}108 \\
(32 \cdot 3)\end{array}$ & $\begin{array}{l}55 \\
(16 \cdot 5)\end{array}$ & $\begin{array}{c}334 \\
(100)\end{array}$ \\
\hline
\end{tabular}

NT, non-typable.

None of the putative marker combinations $c^{\alpha} / R, c^{\beta} / R$, and $c^{\alpha \beta} / R$ was detected. 


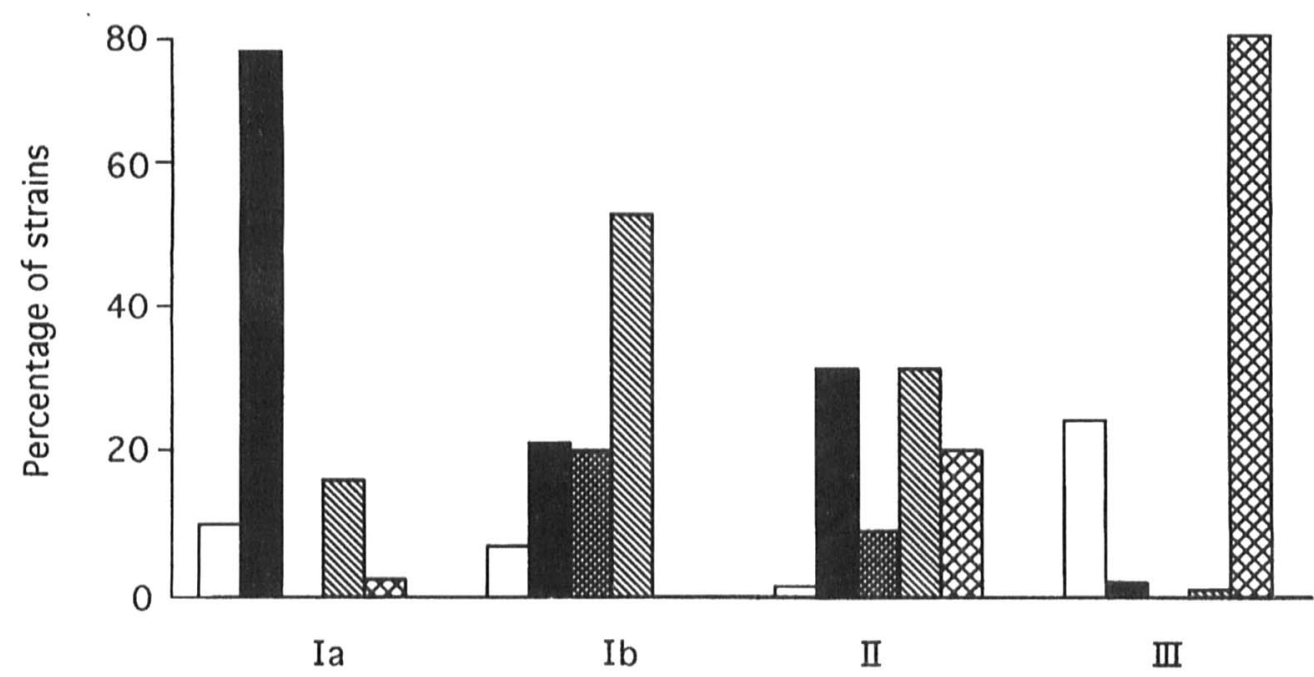

$\mathrm{CHO}$ antigen type

Fig. 1. Association of protein antigens with $\mathrm{CHO}$ antigen type: $\square$, no protein antigen; $\mathbf{\square}, \mathrm{c}^{\alpha} ; \mathrm{c}^{\beta} ; \mathbb{\nabla}, \mathrm{c}^{\alpha \beta} ; \otimes, \mathbf{R}$.

Table II. Distribution of GBS capsular antigen types by clinical sources

\begin{tabular}{|c|c|c|c|c|c|c|c|c|}
\hline \multirow{2}{*}{$\begin{array}{l}\text { Source of } \\
\text { GBS }\end{array}$} & \multirow{2}{*}{$\begin{array}{c}\text { Number of } \\
\text { isolates }\end{array}$} & \multicolumn{7}{|c|}{ Number $(\%)$ of strains of serotype } \\
\hline & & Ia & $\mathrm{Ib}$ & II & III & IV & V & NT \\
\hline Carriers & 108 & $24(22)$ & $9(8)$ & $10(9)$ & $35(32)$ & $9(8)$ & $10(9)$ & $11(10)$ \\
\hline $\begin{array}{l}\text { Neonatal } \\
\text { infection }\end{array}$ & 67 & 7 (10) & $14(21)^{*}$ & $5(7)$ & $35(52) \dagger$ & $2(3)$ & $3(5)$ & $1(2)$ \\
\hline $\begin{array}{l}\text { Adult } \\
\text { infection }\end{array}$ & 159 & $27(17)$ & $49(30) \ddagger$ & $20(12)$ & $43(27)$ & 0 & $5(3)$ & $15(9)$ \\
\hline
\end{tabular}

$*_{\mathrm{p}}<0.02$ when carriers and neonatal infection cases were compared by $\chi^{2}$ test.

tp $<0.01$ when compared to carriers by $\chi^{2}$ test.

$\ddagger \mathrm{p}<0.001$ when compared to carriers by $\chi^{2}$ test.

Table III. Distribution of the $\mathrm{c}^{\alpha}, \mathrm{c}^{\beta}$ and $\mathrm{R}$ protein antigens in GBS by clinical source

\begin{tabular}{lcccccc}
\hline \multirow{2}{*}{$\begin{array}{l}\text { Source of } \\
\text { GBS }\end{array}$} & $\begin{array}{c}\text { Number of } \\
\text { isolates }\end{array}$ & \multicolumn{5}{c}{ Number $(\%)$ of strains with protein antigen } \\
\cline { 3 - 7 } & 108 & $34(32)$ & $4(4)$ & $9(8)$ & $41(38)$ & $20(19)$ \\
\hline $\begin{array}{l}\text { Carriers } \\
\begin{array}{c}\text { Neonatal } \\
\text { infection }\end{array}\end{array}$ & 67 & $14(21)$ & $3(4)$ & $9(13)$ & $25(37)$ & $16(24)$ \\
$\begin{array}{c}\text { Adult } \\
\text { infection }\end{array}$ & 159 & $42(26)$ & $12(8)$ & $44(28)^{*}$ & $41(26)$ & $20(13)$ \\
\hline
\end{tabular}

${ }^{*} \mathrm{p}<0.001$ when compared to carriers by $\chi^{2}$ test.

common $\mathrm{CHO}$ antigen types. The carrier isolates from neonates and adults were grouped together, because the serovariant distributions were very similar.

Strains of the major CHO types, Ia, Ib and III, represented $62 \%, 83 \%$ and $74 \%$ of carrier, neonatal infection and adult infection isolates, respectively. Compared with the carrier isolates, GBS that expressed the $\mathrm{CHO}$ antigen Ib or III occurred with greater frequency in cases of neonatal infection and strains that expressed the $\mathrm{Ib}$ antigen in adult cases (table II). Strains of serotypes II, IV, V and NT, with or without the expression of protein markers, were isolated from carriers and cases. Of the protein markers, the $\mathrm{c}^{\alpha \beta}$ combination occurred more frequently in the adult infection isolates than in the carrier isolates (table III). This was clearly related to the high frequency of type Ib isolates in adults with infections and the fact that many ( $52 \%$ ) of Ib isolates possessed the $\mathrm{c}^{\alpha \beta}$ combination. None of the other $\mathrm{CHO}$ antigenprotein associations occurred with higher frequency in the invasive isolates than in the carrier isolates. Subtype Ia $/ \mathrm{c}^{\alpha}$ occurred in $79 \%$ of the type Ia carrier 


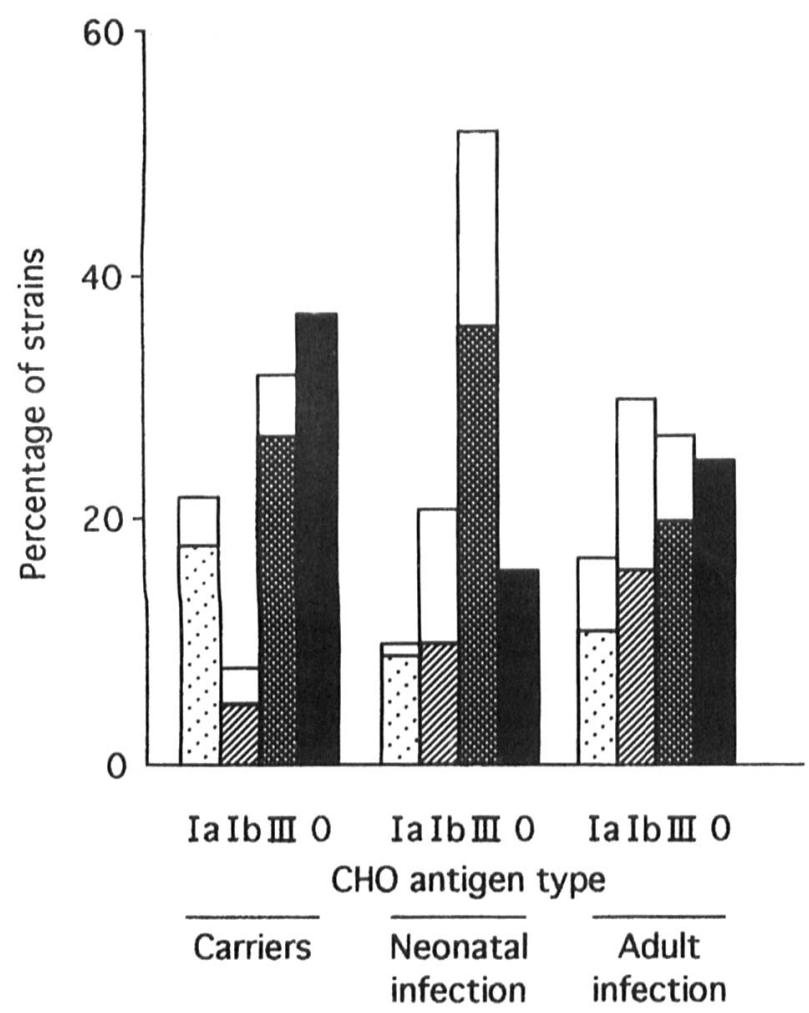

Fig. 2. Distribution of subtype antigens in the most common $\mathrm{CHO}$ antigen types: $\mathrm{O}, \mathrm{Ia} / \mathrm{c}^{\alpha} ; \bigotimes, \mathrm{Ib} / \mathrm{c}^{\alpha \beta} ; \mathrm{III} / \mathrm{R} ; \mathbf{\square}$, other $(\mathrm{O}) \mathrm{CHO}$ types: $\square$, other subtypes with $\mathrm{CHO}$ antigen types Ia, Ib and III.

strains and $67 \%$ of case isolates, subtype $\mathrm{Ib} / \mathrm{c}^{\alpha \beta}$ in $56 \%$ and $51 \%$ and subtype III/R in $83 \%$ and $69 \%$, respectively.

Of the 29 different serovariants detected in the whole strain collection, 24 variants were detected among the carrier strains, 13 among the neonatal infection isolates, and 23 among the isolates from adults with GBS infections.

\section{Discussion}

The $\mathrm{c}$ proteins $\alpha$ and $\beta$ have been well documented $10-12$ as well as the characters of the MAbs to these proteins used in this study. ${ }^{17,18}$ The identity of the protein targeted by the third MAb is less certain, but some observations are consistent with this being an $\mathrm{R}$ protein. ${ }^{19}$ Also, work in progress has shown that this $\mathrm{MAb}$ cross-reacts with the $\mathrm{R} 4$ protein studied by Flores and Ferrieri ${ }^{14}$ and also with protein Rib described by Stålhammer-Carlemalm et al. ${ }^{20}$ These data suggested that the target for the anti-R protein $\mathrm{MAb}$ is the $\mathrm{R} 4$ protein.

The distribution of GBS CHO types in our strain collection largely corresponds with that of other countries. ${ }^{14,21,22}$ Type III GBS was the most frequent, as in other GBS strain collections. ${ }^{14,21,22}$ Strains of all seven $\mathrm{CHO}$ types included isolates that expressed one or two of the protein markers or neither. Of all the isolates tested, $51 \%$ produced c protein $(27 \% \alpha, 6 \% \beta$ and $19 \%$ both $\alpha$ and $\beta$ ) and $32 \%$ expressed the R protein.
Certain capsular CHO types were associated with particular protein markers: the type Ia antigen with $\mathrm{c}^{\alpha}$, type Ib with the $\mathrm{c}^{\alpha \beta}$ combination and type III with the $\mathrm{R}$ protein. ${ }^{14}$ However, each of the protein markers may also be produced by strains of other CHO types consistent with the supposition that expression of the genes encoding these proteins does not depend on synthesis of the favoured $\mathrm{CHO}$ antigen. The $\mathrm{c}$ proteins $\alpha$ and $\beta$ can be expressed by the same GBS isolate, most frequently by type Ib isolates.

Simultaneous expression of $\mathrm{R}$ and $\mathrm{c}$ protein was not detected, although combined expression of these proteins has been reported as a rare event. ${ }^{14}$ Hitherto it has been considered that type Ib GBS always produce c protein but $7 \%$ of our Ib isolates did not. It is tempting to speculate as to whether these strains harbour c protein gene(s) that are not expressed.

Whereas the $\mathrm{CHO}$ antigen determination enabled classification of the 334 isolates into seven different categories, the combination of this typing method with protein antigen testing enabled identification of 29 different serovars; thus the combined approach may prove useful in epidemiological studies of GBS. It is not known how this approach will compare with DNA typing methods used previously. ${ }^{4,5}$

The prevalence of certain $\mathrm{CHO}$ types among the invasive isolates was higher than among the carrier strains, particularly type III and to a lesser extent Ib strains in infected neonates, and Ib strains in adult infections. Although the individuals from whom the carrier strains were isolated, neonates and adult women, may not match the groups with clinical disease, particularly the adults, who were both women and men, these observations are in accord with the anticipated role of GBS capsular antigens as virulence factors, type Ib and type III antigens being potent virulence factors. ${ }^{72}$ An alternative explanation might be that insufficient immunoprotection against type Ib and type III GBS is more common than against GBS of other CHO types. The levels of immunoprotection in the populations studied are not known.

Despite the dominance of type Ib and type III GBS among the invasive isolates, isolates of all the serotypes, whether they produced protein or not, could be invasive. Also, these results show that the proportion of invasive isolates that expressed a single protein or the $\mathrm{c}^{\alpha \beta}$ combination, corresponded to that of the carrier isolates. On the basis of these findings it would seem that the surface-exposed proteins have little if any importance in the virulence of GBS; this was also noted by Chun et al. ${ }^{21}$

Despite this, reported data have indicated an important role for these proteins as targets for protective antibodies. ${ }^{24,25}$ Our findings support the notion that expression of invasiveness by GBS requires the interaction of multiple microbial factors, not only the surface-exposed antigens.

In summary, testing of GBS with antibodies to the surface-exposed $\mathrm{c}$ proteins and an $\mathrm{R}$ protein greatly enhanced the power of the conventional $\mathrm{CHO}$ antigen 
typing system to identify unrelated GBS isolates. Furthermore, the findings are consistent with the role of $\mathrm{CHO}$ serotype antigens in the expression of invasiveness by GBS, particularly the type Ib and type

\section{References}

1. Walsh JA, Hutchins S. Group B streptococcal disease: its importance in the developing world and prospect for prevention with vaccines. Pediatr Infect Dis $J 1989 ; 8$ : 271-276.

2. Colman G. Typing of Streptococcus agalactiae (Lancefield group B). Eur J Clin Microbiol Infect Dis 1988; 7: 226-231.

3. Musser JM, Mattingly SJ, Quentin R, Goudeau A, Selander RK. Identification of a high-virulence clone of type III Streptococcus agalactiae (group B streptococcus) causing invasive neonatal disease. Proc Natl Acad Sci USA 1989; 86: $4731-4735$.

4. Denning DW, Baker CJ, Troup NJ, Tompkins LS. Restriction endonuclease analysis of human and bovine group B streptococci for epidemiologic study. $J$ Clin Microbiol 1989; 27: 1352-1356.

5. Fasola E, Livdahl C, Ferrieri P. Molecular analysis of multiple isolates of the major serotypes of group B streptococci. $J$ Clin Microbiol 1993; 31: 2616-2620.

6. Jelínková J, Matlová J. Worldwide distribution of two new serotypes of group B streptococci: type IV and provisional type V. J Clin Microbiol 1985; 21 : 361-362.

7. von Hunolstein C, D'Ascenzi S, Wagner B et al. Immunochemistry of capsular type polysaccharide and virulence properties of type VI Streptococcus agalactiae (group B streptococci). Infect Immun 1993; 61 : 1272-1280.

8. Lancefield RC, McCarty M, Everly WN. Multiple mouseprotective antibodies directed against group B streptococci. Special reference to antibodies effective against protein antigens. $J$ Exp Med $1975 ; 142$ : 165-179.

9. Bevanger L, Mæland JA. Complete and incomplete Ibc protein fraction in group B streptococci. Acta Path Microbio Scand Sect B 1979; 87: 51-54.

10. Bevanger L, Iversen O-J. The Ibc protein fraction of group B streptococci: characterization of protein antigens extracted by Hcl. Acta Path Microbiol Scand Sect B 1981; 89: 205-209.

11. Hedén L-O, Frithz E, Lindahl G. Molecular characterization of an $\operatorname{IgA}$ receptor from group $B$ streptococci: sequence of gene, identification of a proline-rich region with unique structure and isolation of $\mathrm{N}$-terminal fragments with $\mathrm{IgA}$ binding capacity. Eur J Immunol 1991; 21 : 1481-1490.

12. Michel JL, Madoff LC, Olson K et al. Large, identical, tandem repeating units in the $C$ protein alpha antigen gene, $b c a$, of group B streptococci. Proc Natl Acad Sci USA 1992; 89 10060-10064.

13. Bevanger L. Ibc proteins as serotype markers of group B
III antigens, and the surface-exposed proteins may be less important in this context.

We are grateful to all the clinical microbiologists in England and Wales and Norway who referred these study isolates.

streptococci. Acta Path Microbiol Immunol Scand Sect B 1983; $91: 231-234$

14. Flores AE, Ferrieri $\mathbf{P}$. Molecular species of $\mathbf{R}$-protein antigens produced by clinical isolates of group B streptococci. J Clin Microbiol 1989; 27 : 1050-1054.

15. Wilkinson HW, Facklam RR, Wortham EC. Distribution by serological type of group B streptococci isolated from a variety of clinical material over a five-year period (with special reference to neonatal sepsis and meningitis). Infect Immun $1973 ; 8: 228-235$.

16. Bevanger L, Mæland JA. Type classification of group B streptococci by the fluorescent antibody test. Acta Path Microbiol Scand Sect B 1977; 85: 357-362.

17. Naess AI, Bevanger L, Iversen O-J, Maeland JA. Evaluation of monoclonal antibodies in serovar classification of group B streptococci (GBS). APMIS 1991; 99: 1058-1060.

18. Bevanger L, Iversen O-J, Naess AI. Characterization of the $\alpha$ antigen of the c proteins of group B streptococci (GBS) using a murine monoclonal antibody. APMIS 1992; 100: $57-62$.

19. Kvam AI, Bevanger LS, Iversen O-J. Characterization of a surface protein of group B streptococci resembling the $\alpha$ antigen of the c proteins. In: Totolian A (ed) Pathogenic streptococci in present and future. St Petersburg, Lancer Publications. 1994: 337.

20. Stålhammar-Carlemalm M, Stenberg L, Lindahl G. Protein Rib. A novel group B streptococcal cell surface protein that confers protective immunity and is expressed by most strains causing invasive infections. J Exp Med 1993; 177: 1593-1603.

21. Chun CSY, Brady LF, Boyle MDP, Dillon HC, Ayoub EM. Group B streptococcal c protein-associated antigens: association with neonatal sepsis. J Infect Dis 1991; 163: 786-791.

22. Hervás JA, González L, Gil J, Paoletti LC, Madoff LC, Benedi VJ. Neonatal group B streptococcal infection in Mallorca, Spain. Clin Infect Dis 1993; 16: 714-718.

23. Baker CJ, Edwards MS. Group B streptococcal infections. In: Remington JS, Klein JO (eds) Infectious diseases of the fetus and newborn infant, 3rd edn. Philadelphia, W. B. Saunders Company. 1990: 742-811.

24. Bevanger L, Naess AI. Mouse protective antibodies against the Ibc proteins of group B streptococci. Acta Pathol Microbiol Immunol Scand Sect B 1985; 93: 121-124.

25. Michel JL, Madoff LC, Kling DE, Kasper DL, Ausubel FM. Cloned alpha and beta c-protein antigens of group B streptococci elicit protective immunity. Infect Immun 1991; 59: 2023-2028. 